\title{
Consumer Loyalty and Brand Marketing Programs in an Emerging Economy: Evidence from the Automobile Industry
}

\author{
Sayibu Ibrahim Nnindini ${ }^{1 *} \&$ Justice Boateng Dankwah ${ }^{2}$ \\ 1Department of Distance Education, School of Continuing and Distance Education, University of Ghana, Accra, \\ Ghana \\ ${ }^{2}$ Department of Entrepreneurship and Business Science, University of Energy and Natural Resources, \\ Sunyani, Ghana \\ nnindini@yahoo.com, sayibu65@gmail.com,jboatengdankwah@yahoo.com, justice.dankwah@uenr.edu.gh
}

\begin{abstract}
The study examined the relationship between brand marketing programs and brand loyalty of automobile users in an emerging economy context. Adopting a positivist paradigm, a quantitative approach was employed. Using a cross-sectional survey, data was collected from 700 respondents. Scales of measures were evaluated using exploratory and confirmatory factor analysis after which consumer loyalty segments were created using cluster analysis. Logistic regression was carried out to evaluate the effect of brand marketing programs on consumer loyalty. The study revealed a positive and significant association between brand marketing efforts and consumers' purchase decisions and loyalty to automobile brands. Four brand marketing efforts were also found to be significantly associated with the two segments (high and low involvement) at varying degrees.
\end{abstract}

Keywords: Consumer loyalty, Brand Marketing Programs, IMC, Emerging Economies, Automobile.

\section{Introduction}

The mainstream marketing literature is replete with studies conducted on brand loyalty. These studies have churned out different and varied results in developed and developing economies context, with a majority of scholars postulating several precursors of marketing programs for brands as well as factors that influence consumers' emotional attachments to particular brands (Lee et al., 2015; Odoom, 2016). Nonetheless, the finding reported in these studies cannot be generally applied as a result of the differences that exist in the preferences and requirements of consumers across different geographical regions (Bishnoi \& Kumar, 2016) often with different and unique environmental settings (Aksoy et al., 2015; Odoom, 2016). The current study sought to examine brand marketing efforts and consumers in the automobile sector. By recognizing different levels of loyalty, the study assesses the degree of importance of the brand marketing programs on high and low loyalty consumer segments within an emerging market context. With consumers exhibiting varied behavioral patterns in different geographical contexts, researchers in the field of branding have acknowledged the existence of gaps in the concept of brand loyalty and therefore call for further studies to explore the subtleties of consumer brand loyalty in different economic and geographical contexts and also with different brand categories (Bishnoi \& Kumar, 2016; Odoom, 2016). Besides, much has not been achieved in marketing literature in acknowledging the fact that brand loyalty exhibited.

Consumers are at varying degrees (for example high or low involvement) and also dependent on the product category (Bishnoi \& Kumar, 2016). Consequently, the majority of studies on loyalty rarely consider the nuances that exist in the brand loyalty spectrum when carrying out analysis and reporting findings on brand loyalty. Furthermore, a greater number of studies that are focused on consumer and brand loyalty often rely on constructs that have been used over time (Odoom, 2016). Furthermore, the dependence on continuous weights/measures is not likely to paint an accurate picture of the degree of loyalty consumers exhibit towards brands under predetermine predictors. The use of dual or multiple measures by this study would help reveal 'true' loyalty acts. Therefore, there is a call for more interrogation of the effects of consumers' involvement on different nuances of loyalty in different sectors (Ahn \& Back, 2018; Behnam et al., 2020; Foroughi et al., 2019). It is for this reason that Odoom (2016) advocates for further studies in this sphere focusing on finding solutions to the aforementioned issues, lest these gaps continue to the mainstream marketing literature. Odoom (2016) further warned that if the conceptualization on context-based marketing issues is not established researchers in the field of marketing risk being susceptible to leaky quirks. Also, the literature suggests that most of the studies conducted on consumer choice regarding automobiles have largely been carried out in advanced economies (Odoom, 2016; Tang et al., 2011). 
There is therefore dearth of studies on consumer behavior in the automobile industries in emerging market particularly sub-Sahara Africa (Ghana) (Narteh et al., 2012) hence this study. The study sought to achieve three objectives; thus, to examine; (1) the effect of specific brand marketing programs on brand loyalty of automobile users in Ghana, (2) the degree of influence of brand marketing efforts on consumers in both high or low loyalty segments and finally (3) to examine the significance of selected brand marketing activities in predicting the probability of consumers becoming more loyal to their preferred car brands. This study makes two significant contributions; first, the study contributes to the literature on marketing programs and brand loyalty through the application of the Theory of Reason Action (TRA) and the complexity theory in a unique and underrepresented context, sub-Sahara Africa (Ghana). Also, the study validates Keller's (2013) rarely examined view of marketing efforts' impact on customers' loyalty in an underrepresented context; the automobile industry in an emerging economy. Second, the study has the potential to offer practitioners within the automobile industry in Ghana insight through empirical evidence on the nuances and the relationship that exists between their marketing efforts and the expected outcome. The rest of the paper is grouped into 5 sections: literature review, theoretical review, conceptual framework and hypothesis development, methodology, results and implications.

\section{Literature Review}

The concept of brand loyalty is one of the widely researched concepts in the discipline of marketing in the last forty years (Loureiro, Sarmento \& Le Bellego, 2017). As a result of its popularity among researchers and practitioners, several attempts have been made to define the concept. According to Oliver (1999, p.34), brand loyalty can be explained as "a deeply held commitment to rebuy or re-patronize a preferred product/service consistently in the future, thereby causing repetitive same-brand or same-brand-set purchasing, despite situational influences and marketing efforts having the potential to cause switching behavior." In other words, brand loyalty is a manifestation of the positive relationship that is created between customers and brands that results in customers showing commitment to the brand and the willingness to engage in repeat purchases in the future ( $\mathrm{Li}$, Teng \& Chen, 2020; Putra, 2019). There are different typologies and classifications of loyalty. Dick and Basu (1994), for instance, delineated loyalty into four typologies, namely, true loyalty, spurious loyalty, latent loyalty and no loyalty. Day (1969) suggests two indicators, action and affection for brand loyalty and divided brand loyalty into true brand loyalty and spurious brand loyalty. In addition, Oliver (1999) also classifies loyalty into four types: cognitive, affective, conative and action.

To others, loyalty could either be genuine loyalty (Arnold \& Reynolds, 2003) or unauthentic (Iglesias, Singh \& Batista-Foguet, 2011). Unauthentic loyalty is influenced by other factors such as cost and availability (Iglesias et al., 2011). Genuine loyalty on the other is based on emotional attachment for the brand that is developed as a result of a positive experience with the brand over a period of time (Lin, 2010). However, with time, two main brand loyalty dimensions have developed - attitudinal loyalty (measuring consumers' purchase intention and overall feelings about brands) and behavioral loyalty (often considered synonymous with repeat purchase behavior). These two types of loyalty appear to capture all existing categorizations of the construct (Kuikka \& Laukkanen, 2012; Dawes et al., 2015). Inherent in all these conceptualizations is the view that consumers' level of loyalty could be either high or low in most cases. There is consensus in the extant literature (Loureiro, et al., 2017) about the benefits companies could derive from brand loyalty including word of mouth advocacy (Nawaz \& Usman, 2011; Saini \& Singh, 2020; Sutikno, 2011), growth in market share (Aaker, 1996; Gounaris \& Stathakopoulos, 2004; Nawaz \& Usman, 2011), low marketing expenses (Chaudhuri \& Holbrook, 2001; Pupo, 2010), increased bottom line (Kabiraj \& Shanmugan, 2011; Loureiro, et al., 2017) and competitive edge (Iglesias et al., 2011).

According to Behnam et al. (2020), Koenigstorfer and Wemmer (2019) the ability for companies to attract and maintain customers is a function of meeting customers' expectations through sustained delivery of quality service, which is a key predictor of customer satisfaction. Aaker (1996) contends that brand loyalty could be a tool for measuring the overall success of a company's marketing, strategy. When loyal customers become advocates for brands less effort is required for customer education which results in reduced marketing costs (Pupo, 2010). It also offers companies an advantage in negotiations with suppliers and distribution channels. Previous studies suggest that brand loyalty is influenced by varied factors including brand image (Marliawati \& Cahyaningdyah, 2020; Mabkhot et al., 2017), product quality (Angga et al., 2017), 
brand association (Odoom, 2016; Romaniuk \& Nenycz-Thiel, 2013), brand trust (Utomo, 2017), positive brand experience (Marliawati \& Cahyaningdyah, 2020) brand awareness (Utomo, 2017), socio-economic elements (Puspita et al., 2017) and country of origin effect (Bakar et al., 2017; Monica et al., 2019). It is established that contemporary consumers' aspirations go beyond the core product functions to include the added value dimensions of brands such as unique experience and convenience (Mostafa \& Kasamani, 2020). The brand experience could be enhanced by creating the right brand atmosphere and effective marketing communication strategy for the brand (Ong et al., 2018).

Theoretical Review: Consumer brand loyalty could be explained from different theoretical perspectives (Corley and Gioia, 2011; Miles, 2012). The theory to be adopted in explaining consumer brand loyalty is largely influenced by the objective of the study. Hence, scholars have proposed different theories that could be used to explain brand loyalty (Rather, Tehseen, \& Parrey, 2018; Odoom, 2016). For instance, Russo et al. (2016) proposed the use of complexity theory in explaining consumer brand loyalty. Russo et al. (2016) further argue that brand loyalty is essentially about the behavior and attitudes of consumers, which is deemed to be complex; it will therefore require a framework like the complexity theory to better explain the phenomenon. Perhaps, the proponents of the complexity theory are mindful of the fact that constructs relationships might not be linear in real life due to several intervening factors. Hence one cause can generate distinct results in different settings. Others like Lyong Ha (1998) on the other hand, prefer to use the theory of reasoned action (TRA) in explaining the phenomenon of consumer brand loyalty. Lyong Ha (1998) contends that, brand loyalty is multifaceted and that TRA is appropriate in explaining it. This theory was propounded to explain the consumer purchase decision-making process (Fishbein, 1980). As suggested by Lyong Ha (1998), attitude toward purchasing and external factors (subjective norm) are the antecedents of purchase or re-purchase. We find the TRA pertinent to this study, and argue that a person's loyalty to a particular brand could also be influenced by attitude and external factors such as brand marketing programs.

\section{Hypothesis Development and Conceptual Framework}

Brand Marketing Effort: Strong brands have been noted by marketing scholars as the key source of competitive advantage for firms (Aaker, 1996; Hoeffler and Keller, 2003). When a consumer decides to purchase a brand, the consumer is not only buying the brand but also identity in the process (Rather, Tehseen and Parrey, 2018; Wilson and Gilligan 2012). As part of choosing and purchasing a car brand, for example, consumers usually compare brand features such as quality, price and design, engine capacity and durability (Odoom, 2016). The marketing strategies of brands adopted by marketing professionals in persuading consumers about the superiority of the brand attributes is a significant step towards attaining consumer loyalty (Odoom, 2016).

Brand Identities and Brand Loyalty: Brand identification provides an elaborate conceptualization of the special relationship between consumers and brands (Rather, 2017; So et al., 2017; Tuskej \& Podnar, 2018). Brand identities (also known as elements) play vital roles in differentiating companies offering from that of competition. According to Shirazi et al. (2013) brand confers on products' distinctive features which makes it stand out in the marketplace and resonate with a section of customers. Brand elements that align with the beliefs and personality of consumers have been suggested to positively influence the self-esteem and confidence of the consumers (Rather, Tehseen \& Parrey, 2018). Hence consumers purchase brands not only for their functional performance but the value the brands add to building the confidence of the consumer (So et al., 2017). Carefully selected brand elements could therefore facilitate the acknowledgment and brand review by customers in an environment where there are numerous competing alternatives (Sonnier \& Ainslie, 2011). The brand element whether a name, symbol or image has the potential to influence the consumer buying decision process positively. In light of this, it is hypothesized that;

H1: Brand identity has a positive relationship with consumer loyalty to automobile brands.

Marketing Programmes and Brand Loyalty: Marketing programs of brands today are focused on fostering relationships between the consumer and the brand (Kitchen, 2017). Marketing programs are about sharing information with customers that stimulate cognitive activities resulting in the consumer-brand relationship (Kumar, Dash \& Malhotra, 2018). A brand achieves prominence only when the brand elements selected elicit the right associations. Nonetheless, for a brand to attain prominence and stay at the top of the memory of 
consumers, the brand ought to be visible to customers via marketing programs such as advertisement and promotion. Laran et al. (2011) assert that consumers are more likely to purchase brands that are visible and in the top memory of consumers. It is therefore imperative that companies pay attention to marketing strategies that can propel their brands to consumers' evoke set. Machado et al. (2012) contend that all kinds of brands require some marketing activities and programs to escalate their prominence. Previous studies (Hynes, 2009) have reported that marketing programs could be used to keep brands in consumers' memory and induce affective reactions. Keller and Lehman (2006) also report that marketing practitioners often adopt a multiplicity of communication techniques that are blended to promote brand value and promise. This is often done through mediums such as electronic media, print and outdoor advertisement. The increase in popularity of the new media has presented marketing professionals with an additional medium through which important information about brands is communicated (Mitic \& Kapoula, 2012). Kumar, Dash and Malhotra (2018) argue that marketing programs could strengthen the loyalty of consumers to brands. Based on this, it is hypothesized that;

H2: Marketing programs have a positive relationship with consumer loyalty to automobile brands.

Secondary Brand Associations and Brand Loyalty: Aaker (1991) describes brand association as "anything linked in memory to a brand". The best description of consumers' minds would be a battlefield where competing brands struggle for attention. According to Gagnon and Lexchin (2008), companies expend a lot of resources to acquire a space in the consumer's mind. The consumer buying decision-making process is an intense mental activity (Laran et al., 2011). Hence becoming loyal to a brand is a process where a customer develops a special emotional attachment to the brand (Fastoso \& González-Jiménez 2018; Shimul et al., 2019). It is at this point that companies strategize by using brand associations to influence the consumer buying decision-making process. According to Keller (2003), a critical element of building strong brands is creating effective brand association which positively impacts brand equity.

This is a view shared by other scholars who contend that secondary associations serve as cues that remind consumers of particular brands when consumers make purchase decisions (Odoom, 2016; Romaniuk \& Nenycz-Thiel, 2013). It is argued that brand association is a technique used by companies to foster a good bond between brands and consumers to provoke the appropriate response from consumers (Koll \& von Wallpach, 2014). Equally, Brown et al. (2006) observed that secondary associations are signs and symbols used by companies to create awareness about their brands with the ultimate goal of establishing a mutually beneficial relationship between the brand and consumers. Professional views taken together with the findings of empirical research suggest that effectively deployed brand association could result in the desired outcome, that is, loyalty (Odoom, 2016; Thomas, 2015). It is therefore hypothesized that;

H3: Secondary brand association has a positive relationship with consumer loyalty to automobile brands.

Integrated Marketing Communication and Brand Loyalty: As stated early on, strong brands are those that are supported with effective integrated marketing communication (IMC). Oluwafemi and Adebiyi (2018) describe IMC as a communication tool that ensures a two-way flow of information between consumers and brands. Effective marketing communication is customer-centered - thus reflecting the aspirations and expectations of consumers (Hänninen \& Karjaluoto, 2017; Oluwafemi \& Adebiyi, 2018). Currently, the effectiveness of marketing communication is considered a key tool in building strong brands (Keller, 2009). Perhaps this is because firms have realized that IMC has the potential to influence consumer purchase decisions positively. For instance, previous studies suggest that IMC could have a direct and indirect impact on various shades of consumer behavior particularly loyalty to brands (Aaker, 1997; Oluwafemi \& Adebiyi, 2018). For a company's IMC to succeed in delivering a consistent message and achieve strategic positioning in the consumers' minds, the IMC elements have to be effectively integrated (Keller, 2009). Businesses today are broadening the communication mix to include the new media.

Firms use social media to drive sales and consumer loyalty by encouraging consumers to share their brand experience and purchases online to influence behaviors and attitudes among friends (Bilgin, 2018; So, et al., 2017). Considering that most consumers are likely to develop emotional attachment or loyalty to brands that are easily accessible to them to patronize (Uncles et al., 2003), the tactics used in promoting, distributing and selling brands (via marketing channels) can significantly impact sales turnover rate of a brand (Kapferer, 2012). Previous studies have found elements of marketing communication mix (Yeshin, 2012) to have the 
ability to drive and instigate strong customer-brand relationships which eventually could lead to loyalty (Keller, 2009; Schultz et al., 2014). As a result of the wide array of marketing communication channels, it has become necessary to coordinate and harmonize these channels with a uniform message (Payne, Peltier \& Barger, 2017). Previous studies (see Luxton et al., 2017; Porcu et al., 2012; Seric et al., 2014) have suggested a positive relationship between IMC and consumer brand loyalty. In view of this, it is hypothesized that;

H4: IMC has a positive relationship with consumer loyalty to automobile brands.0

Figure 1: Conceptual Framework

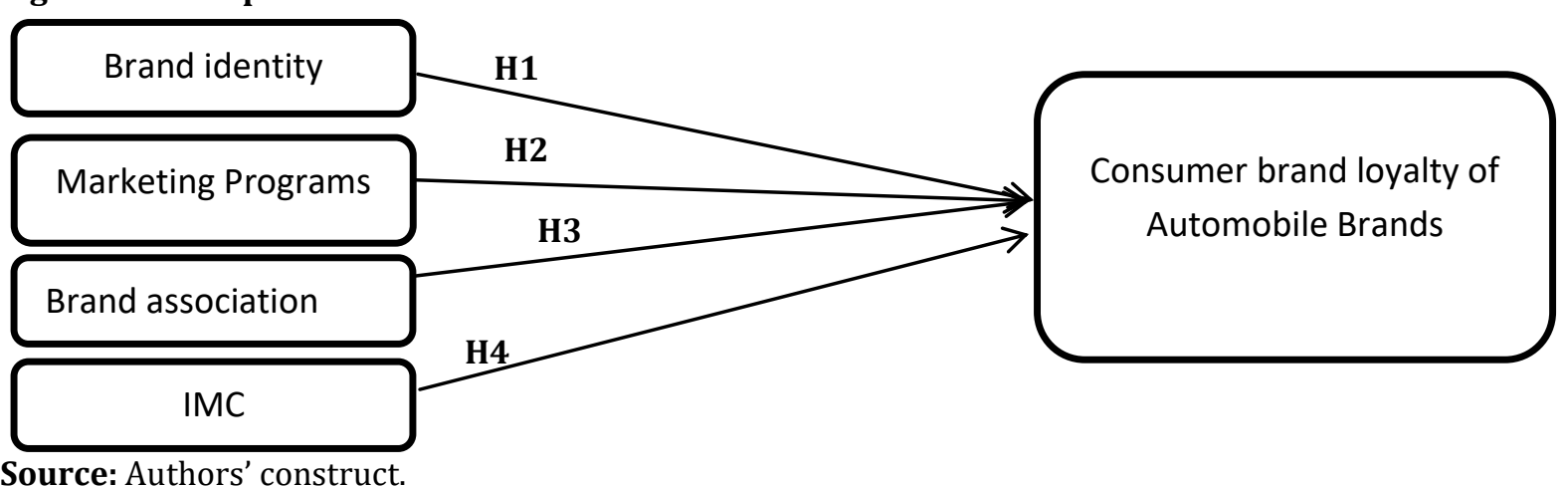

Source: Authors' construct.

\section{Methodology}

Research Instrument: The Questionnaire was the main tool used for data collection in this study (Malhotra $\&$ Birks, 2007). The instrument was structured in three parts. The first part had questions on demographic features of the respondents, covering the age, gender, educational level, number of cars owned, primary car brand and how long a respondent has used their preferred car brand. The second section contained 21 statements on brand marketing efforts adapted from Odoom (2016) and was measured with a Likert scale which ranges from $1=$ not at all, through to $4=$ neutral, to $7=$ extremely important. The third and final section of the questionnaire dealt with statements on brand loyalty, adapted from (Odoom, 2016, Brakus et al., 2009). These were measured on a 7-point Likert scale where $1=$ =xtremely unlikely, $4=$ neutral and 7 =extremely likely.

Sample, Data Collection and Analysis: In preparing for the data collection, the researchers contacted car dealerships and garages in Accra and Kumasi (the two largest cities in Ghana) requesting customers' information. The criteria for the selection of the car dealerships and garages was based on whether a garage deals in at least one of the four car brands the study focused on and also had at least current and up-to-date contact information on customers they transacted business with. In all, seven car dealerships were found useable- four from Accra and three from Kumasi, who shared their customer contact information with the researchers. Purposively selected respondents were contacted on phone for an appointment for questionnaire administration. The respondents were selected based on their usage of at least one of the four car brands (Toyota, Nissan, VW, BMW) the study focused on. The data collection exercise lasted for 8 weeks. As part of the data analysis process various test was conducted. To begin with, the validity and reliability of the measurement scales were determined by carrying out EFA and CFA tests. Next was the extraction was PC factors from the varimax rotation in the EFA which represented the brand marketing effort in the ANOVA test, which was carried out to assess the effect of the selected brand marketing efforts on consumer loyalty in the two segments (high and low). A logistic regression analysis was carried out to evaluate the impact of a brand marketing effort on predicting car users' loyalty towards their primary car brand.

\section{Data Analysis and Results}

Profile of Respondents: The respondents' demographic characteristics as displayed in Table 1 show that majority of the participants in the survey were male representing 53.08 percent while 46.92 percent were females. concerning the ages of respondents, the majority (37.08) of the respondents were in the cohort of 36 years to 45 years, 31.23 percent were in the age category of 46-55, while 16.92 were in the age group of 25- 
35 and those above 55 years made up of 14.77 percent of the sample. This demonstrates that most car users in Ghana are within the economically active year groups. With the educational qualification, 47.08 percent had education up to postgraduate level, 22.15 percent were degree holders, 15.08 percent were diploma holders while 8.9 percent were Ph.D. holders and 6.80 percent were SHS graduates. About the number of cars used by respondents, it was revealed that the majority (59.23 to be exact) use a single car while 40.77 use multiple cars. A further probe about primary car revealed that 44.00 percent of respondents use Toyota as a primary car, Nissan is a primary car for about 25.85 percent of the respondents whereas 16.30 percent use VW as a primary car 13.85 use BMW as a primary car.

Table 1: Characteristics of Respondents

\begin{tabular}{|c|c|c|}
\hline Characteristics & $\mathbf{n}$ & $\%$ \\
\hline \multicolumn{3}{|l|}{ Gender } \\
\hline Male & 345 & 53.08 \\
\hline Female & 305 & 46.92 \\
\hline Total & 650 & 100 \\
\hline \multicolumn{3}{|c|}{ Age of respondents } \\
\hline $25-35$ & 110 & 16.92 \\
\hline $36-45$ & 241 & 37.08 \\
\hline $46-55$ & 203 & 31.23 \\
\hline Above 55 & 96 & 14.77 \\
\hline Total & 650 & 100 \\
\hline \multicolumn{3}{|c|}{ Educational qualification } \\
\hline SHS & 44 & 6.80 \\
\hline Diploma & 98 & 15.08 \\
\hline Degree & 144 & 22.15 \\
\hline Postgraduate & 306 & 47.08 \\
\hline PhD & 58 & 8.9 \\
\hline Total & 650 & 100 \\
\hline \multicolumn{3}{|c|}{ Number of cars used } \\
\hline One & 385 & 59.23 \\
\hline Multiple & 265 & 40.77 \\
\hline Total & 650 & 100 \\
\hline \multicolumn{3}{|c|}{ Primary car brand } \\
\hline Toyota & 286 & 44.00 \\
\hline Nissan & 168 & 25.85 \\
\hline VW & 106 & 16.30 \\
\hline BMW & 90 & 13.85 \\
\hline Total & 650 & 100 \\
\hline \multicolumn{3}{|c|}{ Years with primary car brand } \\
\hline $1-2$ & 122 & 18.77 \\
\hline $3-4$ & 156 & 24.00 \\
\hline $5-6$ & 203 & 31.23 \\
\hline $7-8$ & 83 & 12.77 \\
\hline $9-10$ & 53 & 8.15 \\
\hline Above 10 year & 33 & 5.08 \\
\hline Total & 650 & 100 \\
\hline Note: $n=650$ & & \\
\hline
\end{tabular}


Validity and Reliability of Measurement Scales: The validation of the measurement scales of brand marketing programs was done in 2 phases. First, Exploratory Factor Analysis (EFA) was carried out using principal components extraction and orthogonal varimax rotation techniques. Before the extraction of factors, the Bartlett test of Sphericity showed (Approx.: Chi-square 1/4 8,124.383, df. 753, sig. 0.000) and that Kaiser-Meyer-Olkin statistic (KMO) showed sample adequacy (value of 0.831). This indicated that the variables being measured were significantly correlated to merit the application of EFA. Factors selection was based on eigenvalue being equal to or greater than one (Malhotra \& Birks, 2007). Furthermore, variables selected for the analysis were those whose loadings exceeded 0.5 as well as factors that met suggested reliability criteria of 0.7 (Nunnally, 1978). With regards to consistency internally, Cronbach's $\alpha$ values for the four variables as illustrated in Table II ranged from 0.743 to 0.893 as well as corrected item-to-total correlations all recording values beyond the suggested limit of 0.50 . The second part of the analysis under this section involved confirmatory factor analysis on brand marketing programs and brand loyalty with the help of AMOS.

The fitness of the model was calculated using the Chi-square index ( $\chi^{2} / \mathrm{df}$ ), the goodness of fit index (GFI) and the comparative fit index (CFI). Next was the Tucker-Lewis index (TLI), normed fit index (NFI) and the root mean square error of approximation index (RMSEA) proposed by Anderson and Gerbing (1988). Based on these indices of fitness, the CFA resulted in $\chi^{2} / \mathrm{df}=2.181, \mathrm{GFI}=0.955, \mathrm{CFI}=0.962, \mathrm{TLI}=0.968, \mathrm{NFI}=0.947$ and RMSEA $=0.058$. As illustrated in Table II the results showed that the five constructs' composite reliabilities were in the range of 0.754 to 0.911 which are all above the 0.7 requirements (Nunnally, et al., 1978). Furthermore, the coefficients of the composites relative to the manifest indicators were all significant (see $t$-values $>2.0$ ). Also, the discriminant validity as illustrated in Table 3 was arrived at by juxtaposing the shared values of average variances extracted of pairs of constructs with their squared phi correlations. The results show that all the constructs have AVE values greater than the shared squared phi correlations related to all the constructs and this gives credence to the constructs' discriminant validity. The rest of the descriptive statistics and correlations resulting from the discriminant validity test are displayed in Table 3.

Table 2: EFA and CPA Results

\begin{tabular}{|c|c|c|c|c|c|c|c|c|c|}
\hline \multirow{2}{*}{ Variables } & \multicolumn{4}{|c|}{ EFA Components } & \multicolumn{3}{|c|}{ CPA } & \multirow[b]{2}{*}{ t-value } & \multirow[b]{2}{*}{ CR } \\
\hline & 1 & 2 & 3 & 4 & CITTC & A & $\begin{array}{l}\text { Standard } \\
\text { Loading }\end{array}$ & & \\
\hline $\begin{array}{l}\text { Integrated marketing } \\
\text { communications }\end{array}$ & & & & & & 0.869 & & & 0.878 \\
\hline $\begin{array}{l}\text { Advertising campaigns } \\
\text { deployed by the brand }\end{array}$ & 0.652 & 0.439 & 0.119 & 0.360 & & & 0.972 & Fixed & \\
\hline $\begin{array}{l}\text { Sponsored events by the } \\
\text { brand }\end{array}$ & 0.746 & 0.253 & 0.344 & 0.237 & 0.712 & & 0.821 & 19.317 & \\
\hline $\begin{array}{l}\text { Activities associated } \\
\text { with the brand }\end{array}$ & 0.687 & 0.278 & 0.463 & 0.354 & 0.739 & & 0.767 & 18.686 & \\
\hline $\begin{array}{l}\text { Brochures encouraging } \\
\text { me to buy the brand }\end{array}$ & 0.542 & 0.295 & 0.089 & 0.273 & 0.713 & & 0.763 & 15.395 & \\
\hline $\begin{array}{l}\text { Consumers promotions } \\
\text { on the brand }\end{array}$ & 0.678 & 0.270 & 0.436 & 0.153 & 0.727 & & 0.662 & 18.339 & \\
\hline & & & & & 0.598 & 0.893 & & & 0.868 \\
\hline Brand identities & 0.261 & 0.792 & 0.364 & 0.256 & & & 0.782 & Fixed & \\
\hline The name of the brand & 0.276 & 0.775 & 0.329 & 0.245 & & & 0.673 & 14.805 & \\
\hline Brand features and & 0.319 & 0.619 & 0.097 & 0.271 & 0.578 & & 0.743 & 16.758 & \\
\hline quality & 0.439 & 0.680 & 0.232 & 0.128 & 0.651 & & 0.650 & 14.700 & \\
\hline Logos and symbols of & & & & & 0.601 & & & & \\
\hline brand & 0.471 & 0.6850 .614 & 0.372 & 0.233 & 0.647 & & 0.736 & 16.945 & \\
\hline $\begin{array}{l}\text { Slogans associated with } \\
\text { brand }\end{array}$ & 0.371 & & 0.406 & 0.238 & 0.647 & & 0.696 & 15.882 & \\
\hline characters & & & & & 0.682 & 0.789 & & & 0.861 \\
\hline
\end{tabular}




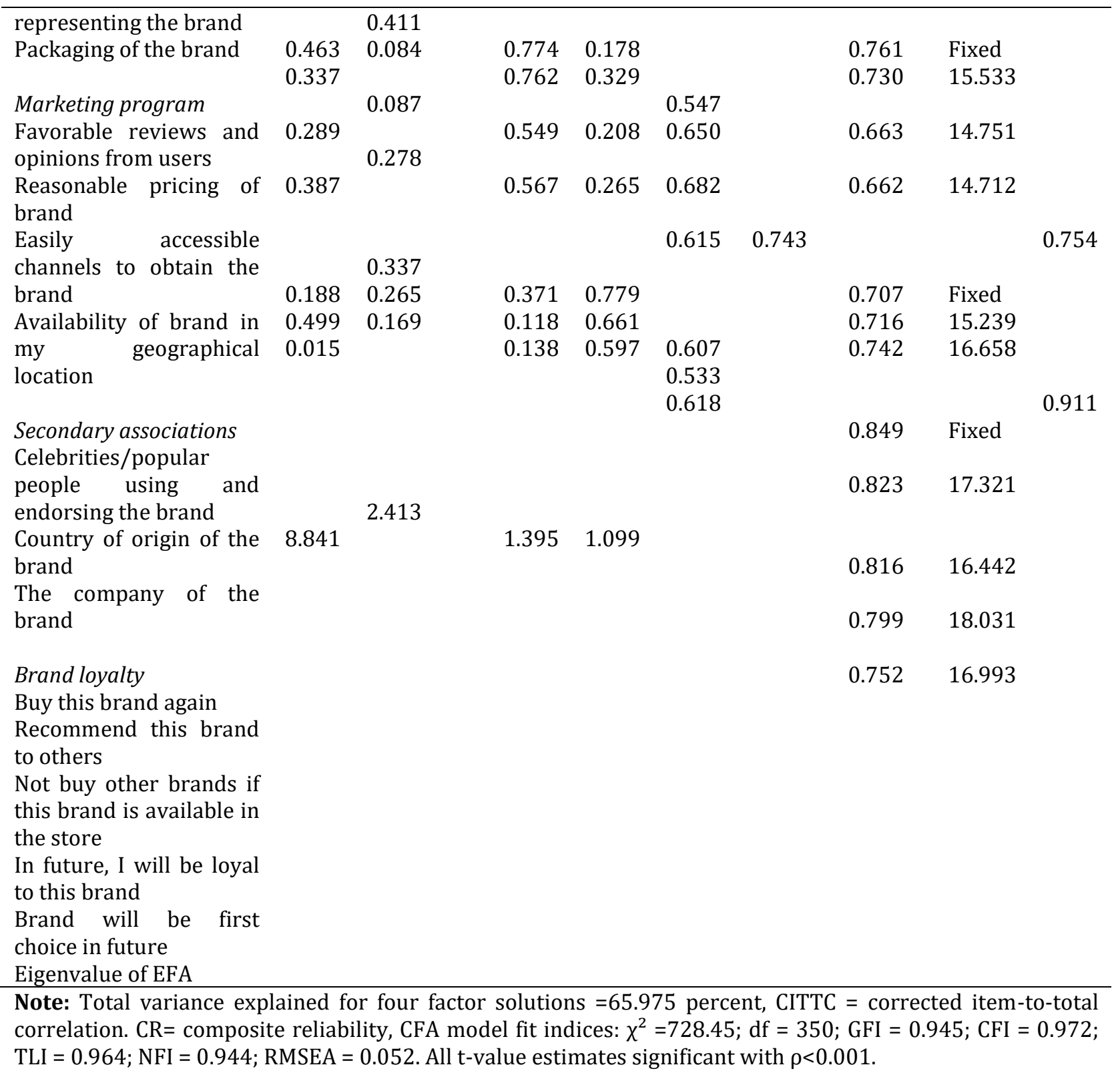

Table 3: Discriminant Validity of Constructs

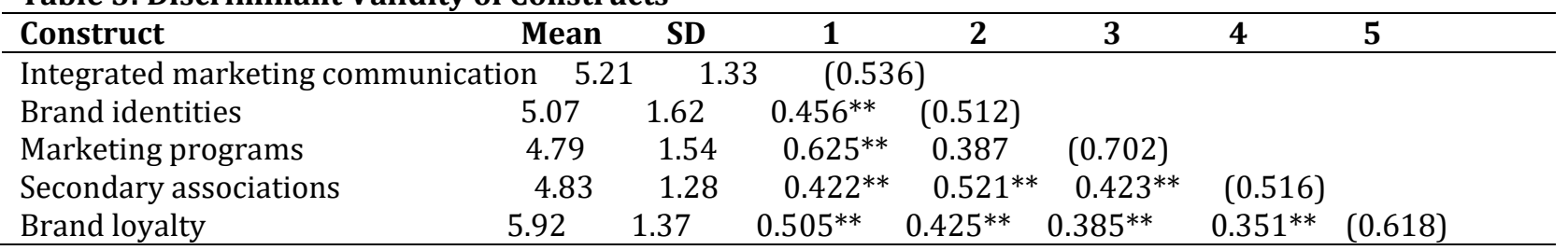

Note: ${ }^{* *}$ Correlation is significant at the 0.01 level (two-tailed); AVE values are on diagonals in brackets.

Cluster Analysis: In furtherance of the aim of the study, it was imperative to assess the level of loyalty of the sampled consumers of the automobile industry. To accomplish this, Ward Algorithm and K-means cluster analysis were adopted for the preliminary analysis which involved the classification of participants into two loyalty segments (high and low). Cluster analysis involves the assigning of cases to predetermined sets (clusters) whose features are usually determined by variables assigned to them by the researcher(s). Hence the consumers were clustered based on the 5 loyalty measures adopted by this study. One of the benefits of 
this approach is that it is insensitive to outliers in the data since its categorization is based on several reiterations (Odoom, 2016). Two clusters emerged after the iteration and were saved for each case. Following this, it was revealed that 390 consumers had high loyalty levels while 260 consumers had low loyalty levels. On the whole, it was found that all the 5 loyalty measures made significant contributions to the categorization process $(F=1,856.902, \rho<0.001)$. The $F=$ statistics showed substantial distinctions among respondents with regards to repeat purchase of the brand $\left(F=532.585^{* * *}\right)$; recommending a brand to others $\left(F=358.435^{* * *}\right)$; not buying other brands $\left(F=655.601^{* * *}\right)$; being loyal to a brand in future $\left(F=286.465^{* * *}\right)$ and brand being the first choice $\left(F=364.602^{* * *}\right)$. The rest of the results of the cluster analysis which illustrates the final clustering centers can be found in Table IV.

Table 4: K-Means Cluster Results

\begin{tabular}{|c|c|c|c|c|c|}
\hline \multicolumn{6}{|c|}{ Clusters Centers Loyalty Level } \\
\hline Loyalty Measures & $\begin{array}{l}\text { High } \\
(n=390)\end{array}$ & $\begin{array}{l}\text { Low } \\
(n=260)\end{array}$ & $\begin{array}{l}\text { Total } \\
\mathrm{n}=265\end{array}$ & F-Value & Significance \\
\hline Buy this brand again & 6.23 & 3.36 & 4.73 & 532.585 & 0.000 \\
\hline Recommend this brand to others & 5.72 & 4.75 & 4.83 & 357.435 & 0.000 \\
\hline Not buy other brands if this one & & & & & \\
\hline is available at the store & 5.74 & 3.63 & 4.88 & 655.601 & 0.000 \\
\hline In future, I will be loyal to this brand & 5.85 & 4.05 & 5.02 & 286.465 & 0.000 \\
\hline Brand will be first choice in the future & 5.98 & 3.98 & 5.00 & 365.602 & 0.000 \\
\hline
\end{tabular}

Notes: *1= extremely unlikely, $7=$ extremely likely.

ANOVA Test: An ANOVA test was carried out to ascertain the significance of brand marketing efforts vis-à-vis the two-consumer loyalty group. The ANOVA test results as displayed in Table 5 show that there is a significant distinction between the two consumers (low and high loyalty) with the four key brand marketing efforts $(\rho<0.001)$. Among the four brand marketing effort measures, "the name of the brand" is found to be the highest differentiator $(F=282.292)$ and the least differentiator was "celebrities/popular people using/endorsing the brand" ( $F=121.983)$. The test results also indicate that the cumulative mean values of the two segments - high and low loyalties favored "favorable reviews/opinions from users" (mean $=5.14$ ) being the highest among the four brand marketing efforts, while "celebrities and popular people endorsing the brand" recorded the lowest mean value (mean $=4.92$ ). Using the scale measures anchor, it is to be noted that a brand marketing effort is considered to be important to consumers if their mean values are equal or greater than the mid-mean value of (4). The results as displayed in Table 5 shows that all the mean values of brand marketing efforts in the high loyalty customer segment are higher as compared to the mean values of the low loyalty customer segment.

Table 5: ANOVA Test Result

\begin{tabular}{|c|c|c|c|c|c|}
\hline \multicolumn{6}{|c|}{ Loyalty of Consumer } \\
\hline Brand Marketing Effortš & $\begin{array}{l}\text { High } \\
\mathrm{n}=390\end{array}$ & $\begin{array}{l}\text { Low } \\
n=260\end{array}$ & $\begin{array}{l}\text { Total } \\
n=265\end{array}$ & $F$-Value & Significance \\
\hline $\begin{array}{l}\text { Celebrities/popular people using/ } \\
\text { endorsing brand }\end{array}$ & 5.46 & 4.37 & 4.92 & 121.983 & 0.000 \\
\hline Favourable reviews/opinions from users & 5.48 & 4.17 & 5.14 & 239.220 & 0.000 \\
\hline The name of the brand & 5.39 & 4.24 & 4.96 & 282.292 & 0.000 \\
\hline Events sponsored by the brand & 5.66 & 4.29 & 5.10 & 177.626 & 0.000 \\
\hline
\end{tabular}

Note: $1=$ not at all important, 5 = extremely important.

Logistic Regression Analysis: To ascertain the brand-specific among the sampled consumers' loyalty and also to determine the predictive ability of the marketing of the brand, a multi-group logistic regression test was carried out. The four items used in the PCA are selected as predictor variables in each model. It is important to note that the dependent variable for this analysis was the two consumer segments (high and low binary) loyalty. As illustrated in Table 6, the model consisting of all the predictors and car brands was found to be statistically significant, thus $\chi^{2}=400.737, \mathrm{df}=4$, value $\rho$ value $<0.001$. The variances in loyalty as accounted for in the model ranges between 33.0 percent (Cox and Snell $R 2$ ) and 44.1 percent (Nagelkerke $R 2$ ) 
while a total extrapolative accuracy of 78.6 percent of all cases was recorded. This suggests that the model indeed was able to make a distinction between the two segments of the consumer.

The four car brands (Toyota, Nissan, VW and BMW) were used to ascertain specific brand loyalty probabilities. Each of the four selected car models - Toyota $\left(\chi^{2}=187.223, \mathrm{df}=5, \rho\right.$-value $\left.<0.001\right)$ : Nissan $\left(\chi^{2}\right.$ $=123.411, \mathrm{df}=7, \rho$-value < 0.001); VW $\left(\chi^{2}=142.121, \mathrm{df}=3, \rho\right.$-value $\left.<0.001\right)$ and $\mathrm{BMW}\left(\chi^{2}=156.341, \mathrm{df}=4\right.$ $\rho$-value $<0.001$ ) were all significant. It is worthy of note that all the models were drawn from high loyalty consumer' groups, this was so because those of the low loyalty consumers' groups were considered as dummies in the logistic regression analysis. The model reveals a predictive accuracy rate of 78.8 percent. The results also indicate that three of the brand marketing effort "events sponsored by the brand" (Wald $=52.687$, $p$-value $<0.001$ ), "name of brand" (Wald $=36.164, p$-value $<0.001$ ) and "favorable reviews and opinions from users" (Wald $=32.742, p$-value $<0.001$ ), all significantly contributed to the model. Furthermore, the odds ratio suggests that any increase in events sponsorship by the brand would see a likely increase in Toyota users' high loyalty to the brand by 2.891 times; 2.196 likelihood of consumers becoming highly loyal as a result of the brand name, and 1.686 likelihood that brand users reviews and opinions would influence consumers to become highly loyal to the brand. The second model recorded a cumulative predictive accuracy of 77.9 percent in all cases.

The results indicate that all four brand marketing efforts, thus "events sponsored by the brand" (Wald = 48.446, $p$-value $<0.001$ ), "name of the brand" (Wald $=26.011, p$-value $<0.001$ ), "celebrities and popular people, endorsing the brand" (Wald $=10.021, p$-value $<0.05$ ) and "favourable reviews and opinions from users" (Wald $=11.598, p$-value $<0.05$ ), significantly contributed to the model. Controlling all other predictors, the odds ratio revealed that users of Nissan are 3.607 times likely to show high loyalty towards the brand when a unit increase in "events sponsored by the brand" occurs; 2.105 chances of becoming a high loyal consumer because of the brand name and 1.567 likelihood of becoming high loyal consumer as a result of the unit "endorsement by celebrities and popular people". The results, however, indicate that there is a 0.620 chance of respondents becoming low loyal consumers to the brand due to "reviews and opinions from other users." With the third model, the total prediction accuracy of 84.7 percent in all cases was recorded. The test results suggest that three brand marketing efforts including "name of brand" (Wald $=27.834, p$-value $<$ 0.001), "celebrities and popular people endorsing the brand" (Wald $=15.323, p$-value $<0.001$ ) and "favorable reviews and opinions from users" (Wald $=8.251, p$-value $<0.05$ ) all significantly contributed to the model. With all other predictors under control, the odds ratio results indicate that there is a 1.616 likelihood of VW customers showing high loyalty to the brand.

Because of the brand name; 1.582 likelihood of consumers would exhibit high loyalty towards the brand if there is a unit more celebrities and popular people endorsement of the brand and 1.291 likelihood of consumers showing high loyalty to the brand as a result of favorable reviews and opinions from other users. With the last model, the cumulative predictive accuracy of 81.5 percent was recorded. The results demonstrate that all four brand marketing efforts thus "events sponsored by the brand" (Wald = 33.643, $p$ value $<0.001$ ), "name of brand" (Wald $=42.342, p$-value $<0.001$ ), "celebrities and popular people endorsing the brand" (Wald $=45.142, p$-value $<0.05$ ) and "favourable reviews and opinions from users" (Wald $=23.670$, $p$-value $<0.05$ ), significantly contributed to the model. With all other predictors under control, the odds ratio results indicate that there is 2.645 likelihood of BMW customers showing high loyalty to the brand because of the brand name; 2.067 likelihood of consumers showing high loyalty to the brand if there is a unit more celebrities and popular people endorsement of the brand; 1.865 likelihood of consumers showing high loyalty to the brand, as a result, favorable reviews and opinions from other users and 2.782 likelihood of consumers showing high loyalty to the brand when there is a unit increase in events sponsored by the brand. 
Table 6: Logistic Regressions with Likelihood Ratio Tests on Loyalty

\begin{tabular}{llcccc}
\hline Car & Brand Marketing Effort & B & Wald & Significance & Odds \\
\hline Toyota & Celebrities/popular people using/endorsing & -0.018 & 0.045 & 0.891 & 0.987 \\
& brand & & & & \\
& Favourable reviews and opinions from users & 0.567 & 20.742 & 0.000 & 1.686 \\
& The name of the brand & 0.782 & 36.164 & 0.000 & 2.196 \\
& Events sponsored by the brand & 1.029 & 44.687 & 0.000 & 2.891 \\
& Celebrities/popular people using/endorsing & 0.465 & 10.021 & 0.002 & 1.567 \\
& brand & & & & \\
& Favourable reviews and opinions from users & -0.483 & 11.598 & 0.001 & 0.620 \\
& The name of the brand & 0.753 & 26.011 & 0.000 & 2.105 \\
& Events sponsored by the brand & 1.410 & 48.446 & 0.000 & 3.607 \\
VWW & 0.397 & 15.323 & 0.000 & 1.582 \\
& belebrities/popular people using/endorsing & & & & \\
& brand & 0.363 & 8.241 & 0.007 & 1.291 \\
& Favourable reviews and opinions from users & 0.574 & 27.834 & 0.000 & 1.616 \\
& The name of the brand & 0.162 & 1.758 & 0.177 & 1.139 \\
& Events sponsored by the brand & 0.654 & 45.142 & 0.002 & 2.067 \\
& Celebrities/popular people using/endorsing & & & & \\
& brand & 0.546 & 23.670 & 0.001 & 1.865 \\
& Favourable reviews and opinions from users & 0.563 & 42.342 & 0.000 & 2.645 \\
& The name of the brand & 0.243 & 33.643 & 0.000 & 2.782 \\
\hline
\end{tabular}

Note: Selection category = high loyalty.

\section{Discussion of Findings}

The study found that brand marketing effort has a significant impact on consumers' purchase decisions and loyalty to automobile brands. In addition, the study sought to assess the degree to which identified brand marketing effort predicted consumers' propensity to exhibit high loyalty towards their primary car brand. The results of the study largely corroborate that of Odoom (2016). Hence the findings of this study contribute to the broadening of the frontiers of both theoretical and empirical research on brand loyalty in several ways. One of such significant contributions of this paper is that it fortifies the significant importance of the concept of branding and how it could help companies stimulate sales and ultimately achieve loyalty if effectively utilized. In consonance with previous studies (Odoom, 2016) and theory advancement; the study consolidates the view that brand marketing effort could positively influence a brand's performance in the marketplace. Furthermore, the study illuminated the levels of importance of brand marketing efforts and their specific effects on consumer loyalty segments and customer loyalty for specific brands. In addition, the results of this study support similar findings in the literature that highlighted the importance of brand elements as vital components of brand marketing programs.

As companies seek to influence consumer buying behavior (Aaker \& Joachimsthaler, 2012; Brakus et al., 2009; Odoom, 2016). Previous studies in the literature (Odoom, 2016; Kapferer, 2012; Tong \& Hawley, 2009) have found that IMC tools such as brand endorsement and sponsorships are vital in courting customer loyalty, a view supported by this study. The findings of this study are also in consonance with the view in literature (Keller, 2009; Schultz et al., 2014; Yeshin, 2012) that effectively deployed IMC tools could lead to consumers developing loyalty towards the company's brands. In sum, this study shares the view espoused by Odoom (2016) that effective utilization of brand associations such as celebrity endorsement and reviews of products could positively influence consumer brand relationships leading to loyalty. Odoom (2016) argues that secondary associations have not been given the credit and attention it deserves in the mainstream marketing literature probably because of the high cost involved in deploying such tools. The findings of this study affirm this assertion as it reveals that the importance of secondary associations cannot be overemphasized particularly in developing economies where consumers' purchase decisions are influenced by the opinions of close relations, associates and influential people (Narteh et al., 2012; Odoom, 2016). 
Theoretical Implications: This study makes modest but significant inputs to the literature and development of the concept of brand loyalty and the marketing literature as a whole. First, it corroborates the basic assumptions of TRA and complexity theory, as the empirical evidence from the study demonstrates that brand loyalty is multifaceted and could churn out different dimensions under different settings (Urry, 2005). This suggests that the marketing activities of global brands could be assessed using theories developed in the developed economies. Second, the technique adopted in examining the loyalty levels in this study is quite different from the approaches adopted in similar studies in the past. For instance, whereas previous studies have largely used a continuous measurement approach, this study distinctively integrated lowly rated responses with highly rated responses. This approach coupled with the use of high loyalty segment in selecting the items in the logistic regression made it possible to distinguish real loyalty from "lower loyalty" responses. Third, the study also contributes to the empirical development of the rarely tested theory (brand marketing effort) of Keller (2013).

Managerial Implications: The findings of this study have some significant implications for the brand manager and general marketing professionals in the automobile industry as a whole. The importance of the findings for companies in the automobile sector stems from the uniqueness of consumer behavior to the geographical context, hence studies conducted in Europe or other developed market contexts would be substantially different from that of a developing market. Equally worthy of note, is the use of four different brands in the same product category which has churned out varied drivers of consumer loyalty across the various brands. The findings present important cues to decision-makers in the automobile industry regarding the marketing effort in support of their brands. For instance, Toyota could increase their budget for events sponsorship in response to the empirical evidence produced by this study which suggests that an increase in events sponsorship by the brand would result in consumers exhibiting high loyalty towards the brand. Besides, marketing professionals and brand managers could be guided by the findings of this study to design marketing strategies that would drive sales and generate loyalty in the emerging market context. Another aspect, of the findings that deserve the attention of practitioners, is consumers' reviews and opinions about the brand as the findings suggest a strong correlation between it and consumer brand loyalty.

\section{Conclusion and Recommendations}

The object of the study was to assess the impact of brand marketing efforts on consumer loyalty at two levels - low and high loyalties among car users. This paper was inspired by the theoretical views of Keller (2013) and the work of Odoom (2016). This study adopted measures of brand marketing program and consumer loyalty from Odoom (2016). The study revealed a positive and significant association between brand marketing efforts and consumers' purchase decisions and loyalty to automobile brands. Four brand marketing efforts were also found to be significantly associated with the two segments (high and low involvement) at varying degrees. These findings reinforce the significant importance of the concept of branding and how it could help companies stimulate sales and ultimately achieve loyalty if effectively deployed.

Limitations and Directions for Future Studies: This study like any literary work is not without limitations. As conceded in the discussions of the findings, consumers' behavior varies based on geographical location hence the findings of this study ought to be interpreted in context and should not be generalized. It would be a useful academic exercise to replicate this study in multiple country contexts to validate the findings of the current study. Moreover, the variables of the study were adopted from the work of Odoom (2016), the discourse on brand marketing efforts would be enhanced if future studies were to identify and use different variables in examining marketing efforts and brand loyalty. Also, the study did not examine the effect of demographic features (age, gender, educational background, etc) on the models tested, it would therefore be interesting to find out how these demographic features could impact and vary the findings of future studies. 


\section{References}

Aaker, D. A. (1996). Measuring brand equity across products and markets. California Management Review, 38(3), 102-120.

Aaker, J. L. (1997). Dimensions of brand personality. Journal of Marketing Research, 34(3), 347-356.

Aaker, D. A. (1991). Managing Brand Equity: Capitalizing on the Value of a Brand Name, the Free Press. New York, NY, 247-248.

Aaker, D. A. \& Joachimsthaler, E. (2012). Brand Leadership. Simon and Schuster.

Ahn, J. \& Back, K. J. (2018). Influence of brand relationship on customer attitude toward integrated resort brands: a cognitive, affective, and conative perspective, Journal of Travel and Tourism Marketing, 35(4), 449-60.

Aksoy, L., Keiningham, T. L., Buoye, A., Larivière, B., Williams, L. \& Wilson, I. (2015). Does loyalty span domains? Examining the relationship between consumer loyalty, other loyalties and happiness. Journal of Business Research, 68(12), 2464-2476.

Arnold, M. J. \& Reynolds, K. E. (2003). Hedonic shopping motivations. Journal of Retailing, 79, 77-95. doi:10.1016/S0022-4359(03)00007-1

Bakar, H. A., Samsudin, S. N. A., Hassan, N. A. \& Abdullah, N. N. B. (2017). Relationship between Country of Origin, Brand Association, Brand Awareness, Brand Loyalty and Perceived Quality. Advanced Journal of Technical and Vocational Education, 1(2), 3.

Behnam, M., Doyle, J. P. \& Delshab, V. (2020). The impact of consumer knowledge on profitable consumer loyalty through perceived service quality and psychological involvement in non-profit sports clubs. International Journal of Sports Marketing \& Sponsorship, 22(2), 407-427.

Bilgin, Y. (2018). The effect of social media marketing activities on brand awareness, brand image and brand loyalty. Business \& Management Studies: An International Journal, 6(1), 128-148.

Bishnoi, V. K. \& Kumar, A. (2016). Aaker's brand personality scale is not universal- explanation and reasons for bikes in India. Journal of Marketing Analytics, 4(1), 14-27.

Brakus, J. J., Schmitt, B. H. \& Zarantonello, L. (2009). Brand experience: what is it? How is it measured? Does it affect loyalty? Journal of Marketing, 73(3), 52-68.

Brown, T. J., Dacin, P. A., Pratt, M. \& Whetten, D. (2006). Identity, intended image, construed image, and reputation: an interdisciplinary framework and suggested terminology. Journal of the Academy of Marketing Science, 34(2), 99-106.

Chaudhuri, A. \& Holbrook, M. B. (2001). The chain of effects from brand trust and brand affects to brand performance: The Role of Brand Loyalty. Journal of Marketing, 65, 81-93. doi:10.1509/jmkg.65.2.81.18255

Corley, K. G. \& Gioia, D. A. (2011). Building theory about theory building: what constitutes a theoretical contribution? Academy of Management Review, 36(1), 12-32.

Dawes, J., Meyer-Waarden, L. \& Driesener, C. (2015). Has brand loyalty declined? A longitudinal analysis of repeat purchase behavior in the UK and the USA. Journal of Business Research, 68(2), 425-432.

Day, G. S. (1969). A two-dimensional concept of brand loyalty. Journal of Advertising Research, 9, 29-35.

Dick, A. S. \& Basu, K. (1994). Customer loyalty: toward an integrated conceptual framework. Journal of the academy of marketing science, 22(2), 99-113.

Fastoso, F. \& González-Jiménez, H. (2018). Materialism, cosmopolitanism, and emotional brand attachment: The roles of ideal self-congruity and perceived brand globalness. Journal of Business Research. https ://doi.org/10.1016/j.jbusr es.2018.12.015.

Fishbein, M. (1980). A Theory of Reasoned Action: Some Application and Implications, NE Symposium on Motivation. University of Nebraska Press.

Foroughi, B., Iranmanesh, M., Gholipour, H. F. \& Hyun, S. S. (2019) Examining relationships among process quality, outcome quality, delight, satisfaction and behavioral intentions in fitness centers in Malaysia, International Journal of Sports Marketing and Sponsorship, 20(3), 374-89.

Gagnon, M. A. \& Lexchin, J. (2008). The cost of pushing pills: a new estimate of pharmaceutical promotion expenditures in the United States. Plos Medicine, 5(1), e1.

Gounaris, S. \& Stathakopoulos, V. (2004). Antecedents and consequences of brand loyalty: An empirical study. Journal of Brand Management, 11, 283-306. doi: 10.1057/Palgrave

Hänninen, N. \& Karjaluoto, H. (2017). The effect of marketing communication on business relationship loyalty. Marketing Intelligence and Planning, 35(4), 458-472. 
Hoeffler, S. \& Keller, K. L. (2003). The marketing advantages of strong brands. The Journal of Brand Management, 10(6), 421-445.

Huang, Y. A., Phau, I. \& Lin, C. (2010). Consumer animosity, economic hardship, and normative influence: how do they affect consumers' purchase intention? European Journal of Marketing, 44(7/8), 909-37.

Hynes, A. (2009). Bridging the trust gap, The Public Relations Strategist, 15(4), 22.

Iglesias, O., Singh, J. J. \& Batista-Foguet, J. M. (2011). The role of brand experience and effective commitment in determining brand loyalty. Journal of Brand Management, 18(8), 570-582. doi: $10.1057 / \mathrm{bm} .2010 .58$

Kabiraj, S. \& Shanmugan, J. (2011). Development of a conceptual framework for brand loyalty: A euromediterranean perspective. Journal of Brand Management, 18(4), 285-299. doi:10.1057/bm.2010.42

Kapferer, J. N. (2012). The New Strategic Brand Management: Advanced Insights and Strategic Thinking. Kogan Page Publishers.

Keller, K. L. (2003). Brand synthesis: The multidimensionality of brand knowledge. Journal of Consumer Research, 29(4), 595-600.

Keller, K. L. \& Lehmannn, D. R. (2006). Brands and branding: research findings and future priorities. Marketing Science, 25(6), 740-759.

Keller, K. L. (2009) Building strong brands in a modern marketing communications environment. Journal of Marketing Communications, 15(2/3), 139-155.

Keller, K. L. (2013) Strategic Brand Management: Global Edition, Pearson Higher Ed, NJ.

Kitchen, P. J. (2017). Integrated marketing communications. Evolution, current status, future developments. European Journal of Marketing, 51(3), 394-405.

Koenigstorfer, J. \& Wemmer, F. (2019). What makes sports clubs successful at recruiting and retaining members from the perspective of managers? Results from a random forest analysis, Journal of Global Sport Management. doi: 10.1080/24704067.2019.1701952.

Kuikka, A. \& Laukkanen, T. (2012). Brand loyalty and the role of hedonic value. Journal of Product and Brand Management, 21(7), 529-537.

Koll, O. \& von Wallpach, S. (2014). Intended brand associations: Do they really drive consumer response? Journal of Business Research, 67(7), 1501-1507.

Kumar, R. S., Dash, S. \& Malhotra, N. K. (2018). The impact of marketing activities on service brand equity. European Journal of Marketing, 52(3/4), 596-618.

Laran, J., Dalton, A. N. \& Andrade, E. B. (2011). The curious case of behavioral backlash: Why brands produce priming effects and slogans produce reverse priming effects. Journal of consumer research, 37(6), 999-1014.

Li, M. W., Teng, H. Y. \& Chen, C. Y. (2020). Unlocking the customer engagement-brand loyalty relationship in tourism social media: The roles of brand attachment and customer trust. Journal of Hospitality and Tourism Management, 44, 184-192.

Loureiro, S. M. C., Sarmento, E. M. \& Le Bellego, G. (2017). The effect of corporate brand reputation on brand attachment and brand loyalty: Automobile sector, Cogent Business \& Management, 4(1), 1360031. DOI: $10.1080 / 23311975.2017 .1360031$

Luxton, S., Reid, M. \& Mavondo, F. (2017). IMC capability: antecedents and implications for brand performance. European Journal of Marketing, 51(3), 421-444.

Lyong Ha, C. (1998). The theory of reasoned action applied to brand loyalty. Journal of Product and Brand Management, 7(1), 51-61.

Mabkhot, H. A., Shaari, H. \& Salleh, S. M. (2017). The influence of brand image and brand personality on brand loyalty, mediating by brand trust: An empirical study. Jurnal Pengurusan, 50(8), 71-82.

Machado, J. C., Vacas-de-Carvalho, L., Costa, P. \& Lencastre, P. (2012). Brand mergers: examining consumers' responses to name and logo design. Journal of Product \& Brand Management.

Malhotra, N. K. \& Birks, D. (2007). Marketing Research, an Applied Approach, European Edition.

Marliawati, A. \& Cahyaningdyah, D. (2020). Impacts the Brand of Experience and Brand Image on Brand Loyalty: Mediators Brand of Trust. Management Analysis Journal, 9(2), 9. https://doi.org/10.15294/maj.v9i2.36945

Miles, J. A. (2012). Management and Organization Theory: A Jossey-Bass Reader. John Wiley and Sons.

Mitic, M. \& Kapoulas, A. (2012). Understanding the role of social media in bank marketing. Marketing Intelligence \& Planning, 30(7), 668-686. 
Monica, D. A., Rini, E. S., Karina, B. \& Sembiring, F. (2019). The Effect of Country of Origin, Price and Quality Perception on Customer Satisfaction and Loyalty at Della Collection Store Medan. International Journal of Research and Review, 6(11), 79-85.

Mostafa, R. B. \& Kasmani T. (2020). Brand experience and brand loyalty: is it a matter of emotions? Asia Pacific Journal of Marketing and Logistics, 33(4), 1033-105. DOI 10.1108/APJML-11-2019-0669

Nawaz, N. \& Usman, A. (2011). What makes customers brand loyal: a study on telecommunication sector of Pakistan. International journal of business and social science, 2(14), 213-221.

Narteh, B., Odoom, R., Braimah, M. \& Buame, S. (2012). Key drivers of automobile brand choice in sub-Saharan Africa: the case of Ghana. Journal of Product and Brand Management, 21(7), 516-528.

Nunnally, J. C. (1978). Psychometric theory (second edition). McGraw-Hill.

Odoom, R. (2016). Brand marketing programs and consumer loyalty - evidence from mobile phone users in an emerging market. Journal of Product \& Brand Management, 25(7), 651-662.

Oliver, R. L. (1999). Whence consumer loyalty? Journal of Marketing, 63(4_suppl1), 33-44.

Oluwafemi, A. J. \& Adebiyi, S. O. (2018). Customer Loyalty and Integrated Marketing Communications among Subscribers of Telecommunication Firms in Lagos Metropolis, Nigeria. Journal of Competitiveness, 10(3), 101-118.

Ong, C.H., Wei Lee, H. \& Ramayah, T. (2018). Impact of brand experience on loyalty. Journal of Hospitality Marketing and Management, 27(7), 755-774.

Payne, E. M., Peltier, J. W. \& Barger, V. A. (2017). Omnichannel marketing, integrated marketing communications, and consumer engagement: A research agenda. Journal of Research in Interactive Marketing, 11(2), 185-197.

Porcu, L., Barrio-García, S. D. \& Kitchen, P. J. (2012). How Integrated Marketing Communications (IMC) works? A theoretical review and an analysis of its main drivers and effects. Communication and Society, 25(1), 313-348.

Pupo, R. (2010). America's Service Meltdown: Restoring Service Excellence in the Age of the Customer: Restoring Service Excellence in the Age of the Customer. ABC-CLIO.

Puspita, R. \& Yunus, M. (2017). Pengaruh faktor sosial, citra merek dan kualitas produk terhadap kepercayaan merek serta dampaknya pada loyalitas pelanggan telepon selular (studi kasus pada pengguna samsung di kota banda aceh). Jurnal Magister Manajemen, 1(1), 46-58.

Putra, B. A. (2019). Pengaruh Citra Merek Dan Persepsi Kualitas Terhadap Loyalitas Merek. Journal of Chemical Information and Modeling, 53(9), 4.

Rather, R. A., Tehseen, S. \& Parrey, S. H. (2018). Promoting customer brand engagement and brand loyalty through customer brand identification and value congruity. Spanish Journal of Marketing-ESIC, 22(2), 321-339.

Rather, R. A. (2017). Investigating the impact of customer Brand identification on hospitality Brand loyalty: a social identity perspective. Journal of Hospitality Marketing and Management, 27(5), 487-513.

Romaniuk, J. \& Nenyez-Thiel, M. (2013). Behavioral brand loyalty and consumer brand associations. Journal of Business Research, 66(1), 67-72.

Russo, I., Confente, I., Gligor, D. M. \& Autry, C. W. (2016). To be or not to be (loyal): is there a recipe for customer loyalty in the B2B context? Journal of Business Research, 69(2), 888-896.

Saini, S. \& Singh, J. (2020). A link between attitudinal and behavioral loyalty of service customers. Business Perspectives and Research, 8(2), 205-215.

Schultz, D. E., Block, M. P. \& Viswanathan, V. (2014). Brand preference being challenged. Journal of Brand Management, 21(5), 408-428.

Šerić, M., Gil-Saura, I. \& Ruiz-Molina, M. E. (2014). How can integrated marketing communications and advanced technology influence the creation of customer-based brand equity? Evidence from the hospitality industry. International Journal of Hospitality Management, 39, 144-156.

Shimul, A. S., Phau, I. \& Lwin, M. (2019). Conceptualizing luxury brand attachment: Scale development and validation. Journal of Brand Management, 1, 2-8. https ://doi.org/10.1057/s4126 2-019-00158 -6.

Shirazi, A., Zeynvand, L. H. \& Karimi, M. A. (2013). Investigating the effects of brand identity on customer loyalty from a social identity perspective. Iranian Journal of Management Studies, 6(2), 153 -178.

Simon, B. \& Reed, J. (2007). Foreigners steer US luxury market, from: http://us.ft.com/ftgateway/superpage.ft?new s_idfto091820071630013971 (accessed August 16, 2011). 
So, K. K. F., King, C., Hudson, S. \& Meng, F. (2017). The missing link in building customer Brand identification: the role of Brand attractiveness. Tourism Management, 59, 640-651.

Sonnier, G. \& Ainslie, A. (2011). Estimating the value of brand-image associations: The role of general and specific brand image. Journal of Marketing Research, 48(3), 518-531.

Sutikno, B. (2011). Does consumers' brand identification matter: The marketing roles of brand loyalty. The International Journal of Interdisciplinary Social Sciences, 6(3), 1833-1882. doi:10.18848/18331882/CGP/v06i03/51695

Tang, Z., Lou, J. \& Xiao, J. (2011). Antecedents of intention to purchase mass customized products. Journal of Product \& Brand Management, 20(4), 316-26.

Thomas, R. J. (2015). Out with the old and in with the new: a study of new kit sponsorship and brand associations in the Barclays Premier League. Journal of Product \& Brand Management, 24(3), 229251.

Tong, X. \& Hawley, J. M. (2009). Measuring customer-based brand equity: empirical evidence from the sportswear market in China. Journal of Product and Brand Management, 18(4), 262-271.

Tuskej, U. \& Podnar, K. (2018). Consumers' identification with corporate brands: Brand prestige, anthropomorphism and engagement in social media. Journal of Product and Brand Management, 27(1), 3-17.

Uncles, M. D., Dowling, G. R. \& Hammond, K. (2003). Customer loyalty and customer loyalty programs. Journal of Consumer Marketing, 20(4), 294-316.

Urry, J. (2005). The complexity turn. Theory Culture and Society, 22(5), 1-14.

Utomo, I. W. (2017). Pengaruh Brand Image, Brand Awareness, dan Brand Trust Terhadap Brand Loyalty Pelanggan Online Shopping (Studi Kasus Karyawan Di BSI Pemuda). Jurnal Komunikasi, VIII(1): 7-8.

Wilson, R. M. \& Gilligan, C. (2012). Strategic Marketing Management, Routledge.

Yeshin, T. (2012). Integrated Marketing Communications, Routledge. 